Jurnal Media Pertanian Vol. 3 No. 2 Tahun 2018 Hal. 99 - 106

Media Komunikasi Hasil Penelitian dan Review Literatur Bidang Ilmu Agronomi ISSN print $2503-1279$

ISSN online $2581-1606$

\title{
PENYAKIT Vascular Streak Dieback (VSD ) \\ PADA TANAMAN KAKAO (Theobroma cacao, L.) \\ SERTA PERSENTASE SERANGANNYA
}

\author{
Yuza Defitri \\ Program Studi Agroteknologi, Fakultas Pertanian Universitas Batanghari \\ Jl. Slamet Riyadi-Broni Jambi, 36122. Telp. +62741 60103 \\ email :yuzadefitri@gmail.com
}

\begin{abstract}
Cocoa is one of the plantation commodities that have high economic value among other plantation crops and plays an important role as a source of foreign exchange through export and encourages regional economics, especially in rural areas. To increase the production of cocoa crops in Betung Village, Kumpeh Ilir District, it is necessary to know the condition of cocoa plants that have the disease and what percentage of the disease attack. It is useful to perform disease control techniques on cocoa plants. This study aims to find out about Vascular Streak Dieback Disease and how many percentages of attacks Vascular Streak Dieback disease. The research was done by Simple Random Sampling method. Crop sampling was done randomly at smallholder cocoa plantations in The Betung Kabupaten Muaro Jambi. Then collect the data by counting all the plants both healthy and sick to get the percentage of plants attacked by using the formula $P=n / N \times 100 \%$. The sample of the cocoa plant affected by Vascular Streak Dieback disease was identified in the Unbari Basic Laboratory. The result showed that there were the attackingof foul fruit disease caused by a Oncobasidium theobromae fungus on passing in land was $80 \%$ which was means it was hard level of disease as more than half cocoafruit were foul. While it showed a light of disease attacking on unpassing in land it's only $30 \%$.

Keywords : Vascular Streak Dieback, Oncobasidium theobromae
\end{abstract}

\begin{abstract}
Abstrak
Kakao merupakan salah satu hasil komoditi perkebunan yang memiliki nilai ekonomis yang cukup tinggi diantara tanaman perkebunan yang lainnya dan berperan penting sebagai sumber devisa negara melalui ekspor dan mendorong ekonomi daerah terutama di pedesaan. Untuk meningkatkan produksi tanaman kakao di Desa Betung Kecamatan Kumpeh Ilir, perlu diketahui keadaan tanaman kakao yang terserang penyakit dan berapa persentase serangan penyakit tersebut. Hal ini berguna untuk melakukan teknik pengendalian penyakit pada tanaman kakao. Penelitian ini bertujuan untuk mengetahui tentang penyakit Vascular Streak Dieback serta persentase serangan penyakit Vascular Streak Dieback tersebut. Penelitian dilakukan dengan metode Simple Random Sampling. Pengambilan sampel tanaman dilakukan secara acak di perkebunan kakao rakyat di desa Betung Kecamatan Muaro Jambi. Data seluruh tanaman yang sehat maupun yang sakit dikumpulkan, sehingga diperoleh persentase tanaman terserang penyakit. Sampel bagian tanaman kakao yang terserang penyakit
\end{abstract}

Diterbitkan oleh Program Studi Agroteknologi Fakultas Pertanian Universitas Batanghari Jambi Halaman 99 
Jurnal Media Pertanian Vol. 3 No. 2 Tahun 2018 Hal. 99 - 106

Media Komunikasi Hasil Penelitian dan Review Literatur Bidang Ilmu Agronomi ISSN print $2503-1279$

ISSN online $2581-1606$

Vascular Streak Dieback diidentifikasi di laboratorium Dasar Universitas Batanghari. Hasil penelitian menunjukkan bahwa persentase serangan penyakit Vascular Streak Dieback yang disebabkan oleh jamur Oncobasidium theobromae pada lahan yang tidak dirawat adalah $80 \%$, yang berarti serangan penyakit ini termasuk berat karena lebih setengahnya buah kakao terserang penyakit, sedangkan pada lahan yang dilakukan perawatan intensif serangan penyakit Vascular Streak Dieback hanya $30 \%$, ini berarti serangan penyakit ringan.

Kata Kunci : Penyakit Vascular Streak Dieback, Oncobasidium theobromae

\section{PENDAHULUAN}

Kakao (Theobroma cacao L.) termasuk kerajaan: Plantae, devisi Magnoliophyta, kelas Magnoliopsida, ordo Malvales, family Malvaceae, genus Theobroma, dan spesies Theobroma cacao.L. Tanaman kakao terdiri atas dua tipe yang dibedakan dari warna bijinya. Kakao yang bijinya berwarna putih termasuk dalam kelompok Criollo sedangkan biji yang berwarna ungu termasuk dalam kelompok Forastero (Susanto, 2010).

Kakao (Theobroma cacao L.) merupakan salah satu komoditi perkebunan yang memiliki nilai ekonomis yang cukup tinggi diantara tanaman perkebunan yang lainnya dan berperan penting sebagai sumber devisa negara melalui ekspor dan mendorong ekonomi daerah terutama di pedesaan. Untuk itu sejak tahun 1980 pemerintah memberikan prioritas untuk mengembangkan tanaman kakao sebagai salah satu komoditas unggulan (Susanto, 2010).

Saat ini Indonesia menjadi produsen utama kakao ke tiga setelah Ghana dan Pantai Gading. Luas tanaman kakao di Indonesia 1.774.303,97 ha (tahun 2014) dengan produksi 777.500 ton dan sekitar $90 \%$ diusahakan oleh rakyat. Sulawesi merupakan daerah penghasil kakao terbesar di Indonesia, 60\% dari luas kakao Indonesia terdapat di Sulawesi yang menyumbang produksi nasional hingga 500 juta ton. Urutan yang kedua adalah Sumatera dengan luas area mendekati 300.000 ha, yang menyumbang produksi hingga 150.000 ton (Direktorat Jendral Perkebunan, 2015).

Menurut Biro Pusat Statistik Provinsi Jambi (2014), luas area tanaman kakao sekitar 2.242 ha dengan produksi 476 ton, sedangkan luas area di Kabupaten Muaro Jambi 618 ha dengan produksi 271 ton.

Salah satu penyebab rendahnya produksi tanaman kakao tersebut adalah karena terserang penyakit. Setiap tahun kerugian yang ditimbulkan bisa mencapai jutaan rupiah setiap hektar tanaman. Penyebab penyakit yang sering dijumpai pada tanaman kakao adalah jamur, sedangkan bakteri atau virus jarang dijumpai dan tidak menimbulkan kerusakan yang berarti (Semangun, 1990 ).

Berikut ini ada beberapa jenis penyakit yang menyerang kakao di perkebunan yaitu, penyakit Vascular Streak Dieback (VSD), penyakit Busuk Buah (Phytophthora palmivora), dan penyakit Kanker Batang (Phytophthora palmivora) (Semangun, 2000).

Penyakit VSD sebagai penyakit mati pucuk merupakan salah satu penyakit utama tanaman kakao, tersebar di Sulawesi Tenggara, Kalimantan Timur, Halmahera, Jawa Barat dan beberapa lokasi lainnya. Penyakit semakin meningkat

Diterbitkan oleh Program Studi Agroteknologi Fakultas Pertanian Universitas Batanghari Jambi Halaman 100 
Jurnal Media Pertanian Vol. 3 No. 2 Tahun 2018 Hal. 99 - 106

Media Komunikasi Hasil Penelitian dan Review Literatur Bidang Ilmu Agronomi ISSN print $2503-1279$

ISSN online $2581-1606$

bila suatu lokasi dengan kelembaban dan curah hujan tinggi. Penyakit menyerang pucuk tanaman dewasa maupun pucuk tanaman muda yang belum membentuk jorket (prapatan) pada batangnya (Semangun, 1990 ).

Penyakit tanaman di lapangan dapat dikenali berdasarkan tanda dan gejala penyakit. Tanda penyakit merupakan bagian mikroorganisme patogen yang dapat diamati dengan mata biasa yang mencirikan jenis penyebab penyakit tersebut. Misalnya miselia yang berbentuk seperti kapas, merupakan salah satu tanda jamur patogen yang menginfeksi tanaman tersebut. Gejala pada umumnya sangat spesifik tergantung pada spesies yang menginfeksinya, sehingga gejala penyakit tersebut dapat dipergunakan untuk mengidentifikasi jenis patogen yang menginfeksi di lapangan (Agrios, 1999).

Penyakit tanaman dapat mengakibatkan kerugian baik secara kuantitas maupun kualitas hasil panen. Upaya untuk mengurangi kerugian akibat infeksi penyakit tanaman tersebut dapat dilakukan pengendalian dengan sasaran dan cara yang tepat. Pengamatan yang dini dan identifikasi penyakit yang tepat akan menjamin keberhasilan pengendalian (Abadi,2005).

Untuk meningkatkan produksi tanaman kakao di Desa Betung Kecamatan Kumpeh Ilir perlu diketahui keadaan tanaman kakao yang terserang penyakit dan berapa persentase serangan penyakit tersebut. Hal ini berguna untuk melakukan teknik pengendalian penyakit pada tanaman kakao.

\section{METODE PENELITIAN}

Penelitian ini telah dilaksanakan di Desa Betung, Kecamatan Kumpeh Ilir, Kabupaten Muaro Jambi dan Laboratorium Universitas Batanghari selama 6 bulan, mulai dari bulan Februari sampai dengan bulan Juli 2018.

Penentuan daerah pengamatan di lapangan dilakukan dengan metode Simple Random Sampling. Pengambilan sampel tanaman dilakukan secara acak di perkebunan kakao rakyat. Pengamatan gejala penyakit Vascular Streak Dieback (VSD) dilakuan secara langsung terhadap kondisi tanaman kakao yang sudah berbuah. Data kumpulkan dengan menghitung seluruh buah, baik yang sehat maupun yang terserang penyakit sehingga didapat persentase tanaman terserang.

Penentuan persentase tanaman terserang dihitung dengan rumus :

$P=n / N x 100 \%$

Keterangan :

$\mathrm{P}=$ Persentase Tanaman terserang $(\%), \mathrm{n}=$ Jumlah Tanaman yang terserang,

$\mathrm{N}=$ Jumlah Tanaman keseluruhan 
Jurnal Media Pertanian Vol. 3 No. 2 Tahun 2018 Hal. 99 - 106

Media Komunikasi Hasil Penelitian dan Review Literatur Bidang Ilmu Agronomi ISSN print $2503-1279$

ISSN online $2581-1606$

\section{Gejala Makroskopis}

Hasil pengamatan secara makroskopis terhadap penyakit yang menyerang tanaman kakao di Desa Betung, Kecamatan Kumpeh Ilir, Kabupaten Muaro Jambi seperti terlihat pada gambar berikut ini :

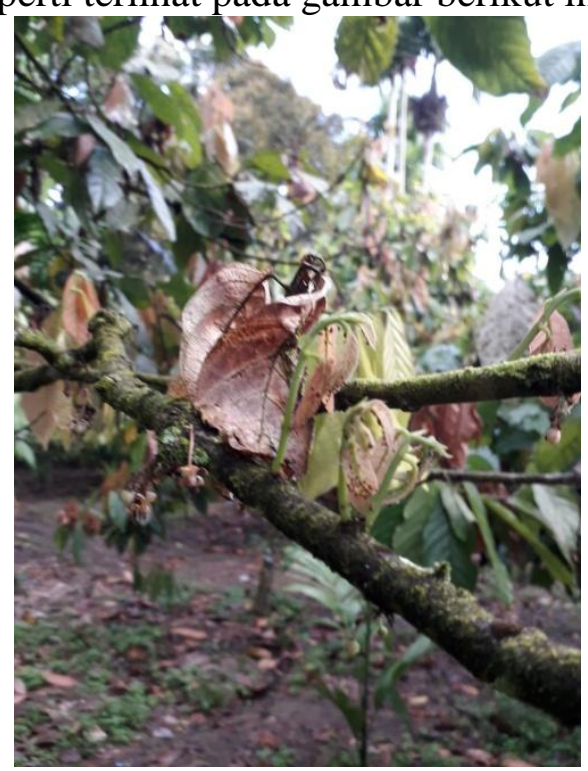

A

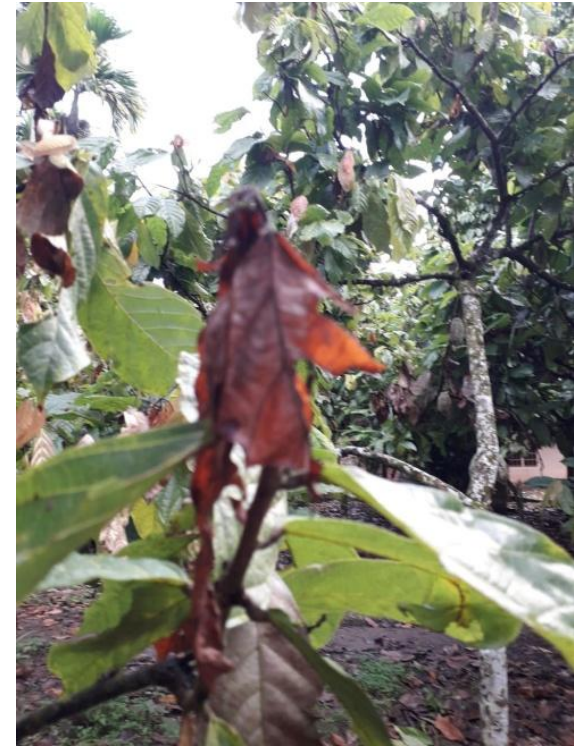

$\mathrm{B}$

Gambar 3. A. Gejala Vascular Streak Dieback pada tunas, daun layu dan mati

B. Gajala Vascular Streak Dieback pada pucuk, daun coklat kehitaman, layu dan mati

Gejala serangan penyakit Vascular Streak Dieback terlihat adanya tunastunas yang baru tumbuh akan layu dan akhirnya mati. Selain itu bagian pucuk tanaman berwarna coklat kehitaman, layu dan mati (Agrios, 1999).

Menurut Semangun (1990), gejala lain dari penyakit Vascular Streak Dieback adalah daun pada flush kedua atau ketiga di belakang titik tumbuh menguning secara khas. Pada daun ini terjadi bercak-bercak hijau kecil yang berbatas tegas, yang tersebar pada latar belakang yang berwarna kuning. Daun yang sakit akan gugur beberapa hari setelah menguning. Gejala penyakit VSD yang ditemukan pada tanaman kakao di perkebunan dapat di lihat pada Gambar 4.

Diterbitkan oleh Program Studi Agroteknologi Fakultas Pertanian Universitas Batanghari Jambi Halaman 102 


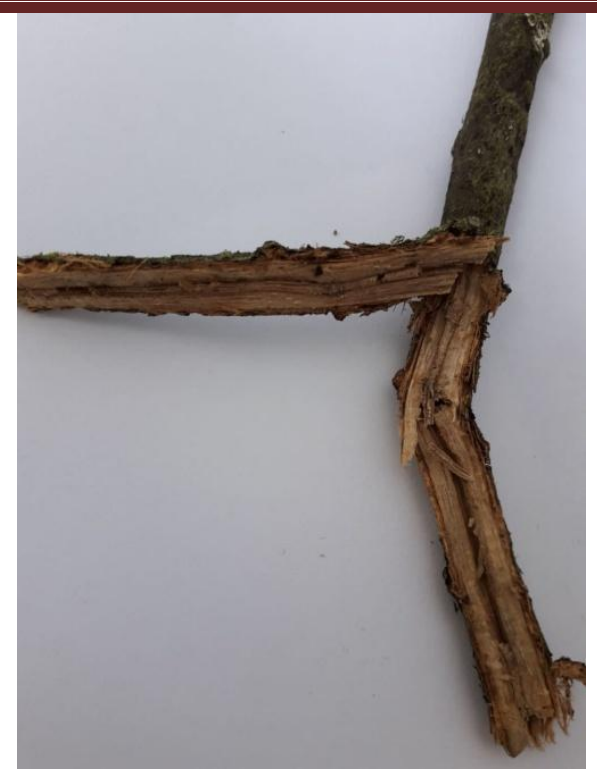

A

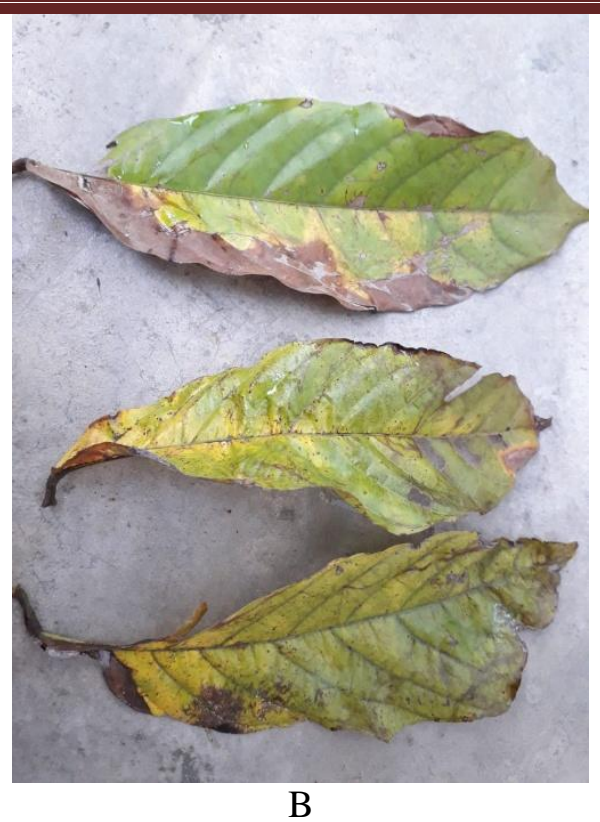

B

Gambar 4. A. Gejala Vascular Streak Dieback (VSD) pada ranting kakao

B. Gejala Vascular Streak Dieback (VSD) pada daun kakao

Gejala lain dari serangan Vascular Streak Dieback yaitu bila ranting dibelah membujur terlihat garis-garis coklat pada jaringan xylem yang bermuara pada bekas duduk daun. Lentisel diranting sakit membesar dan relatif kasar (Semangun, 1990).

Pada ranting yang terserang satu atau dua daun gugur sedang beberapa daun di sebelah bawah dan sebelah atasnya masih lengkap, sehingga tampak gejala ranting ompong. Gejala menguningnya daun mulai terlihat tiga sampai lima bulan setelah spora jatuh pada daun yang bersangkutan, sewaktu daun masih sangat muda (Semangun, 1990).

Menurut Agrios (1999) adanya dijumpai daun yang menunjukkan gejala nekrosis dan klorosis pada daun seperti gejala kekurangan unsur Calsium. Gangguan ini akan segera menyebabkan gugur daun dan mati ranting. 
Jurnal Media Pertanian Vol. 3 No. 2 Tahun 2018 Hal. 99 - 106

Media Komunikasi Hasil Penelitian dan Review Literatur Bidang Ilmu Agronomi ISSN print $2503-1279$

ISSN online $2581-1606$

\section{Persentase Tanaman Terserang Pada Lahan Yang Tidak Dirawat}

Tabel 1. Tanaman Kakao yang Terserang Penyakit VSD pada Lahan yang Tidak Dirawat

\begin{tabular}{clcc}
\hline $\begin{array}{c}\text { No. } \\
\text { pohon }\end{array}$ & Bagian tanaman terserang VSD & $\begin{array}{c}\text { Tanaman } \\
\text { sakit VSD }\end{array}$ & $\begin{array}{c}\text { Tanaman } \\
\text { tidak sakit VSD }\end{array}$ \\
\hline 1 & Pucuk Daun Layu, mati & $\checkmark$ & \\
2 & Ranting ada noktah coklat & $\checkmark$ & \\
3 & Tidak Ada & & \\
4 & Daun Bercak kuning kecoklatan & $\checkmark$ & \\
5 & Ranting ada noktah coklat & $\checkmark$ & $\checkmark$ \\
6 & Pucuk Daun Layu, mati & $\checkmark$ & $\checkmark$ \\
7 & Pucuk Daun Layu, mati & $\checkmark$ & \\
8 & Tidak Ada & & \\
9 & Tidak Ada & & \\
10 & Pucuk Daun Layu, mati & $\checkmark$ & \\
11 & Daun Bercak kuning kecoklatan & $\checkmark$ & \\
12 & Daun Bercak kuning kecoklatan & $\checkmark$ & \\
13 & Pucuk Daun Layu, mati & $\checkmark$ & \\
14 & Pucuk Daun Layu, mati & $\checkmark$ & \\
15 & Ranting ada noktah coklat & $\checkmark$ & \\
16 & Daun Bercak kuning kecoklatan & $\checkmark$ & \\
17 & Pucuk Daun Layu, mati & $\checkmark$ & \\
18 & Daun Bercak kuning kecoklatan & $\checkmark$ & \\
19 & Tidak Ada & & \\
20 & Ranting ada noktah coklat & $\checkmark$ & \\
\hline
\end{tabular}

Dari Tabel 1 di atas dapat dihitung persentase tanaman kakao yang terserang penyakit Vascular Streak Dieback (VSD) pada lahan yang tidak dirawat, yaitu :

$P=n / N x 100 \%$

$P=16 / 20 \times 100 \%=80 \%$

Pada lahan tanaman kakao yang tidak dilakukan perawatan yang intensif yaitu tidak adanya tindakan pengendalian terhadap hama penyakit maka serangan penyakit Vascular Streak Dieback pada lahan tersebut adalah $80 \%$. Hal ini menandakan bahwa serangan penyakit Vascular Streak Dieback yang disebabkan jamur Oncobasidium theobromae adalah berat yang lebih dari 50\%. Tanaman kakao yang dikelola setelah ditanam dibiarkan saja sehingga kondisi kebun banyak ditumbuhi gulma serta jarak tanam yang tidak teratur yang menyebabkan

Diterbitkan oleh Program Studi Agroteknologi Fakultas Pertanian Universitas Batanghari Jambi Halaman 104 
Jurnal Media Pertanian Vol. 3 No. 2 Tahun 2018 Hal. 99 - 106

Media Komunikasi Hasil Penelitian dan Review Literatur Bidang Ilmu Agronomi ISSN print $2503-1279$

ISSN online $2581-1606$

kelembaban tinggi dan cocok untuk perkembangan jamur pathogen penyebab penyakit.

\section{Persentase Tanaman Kakao Terserang Penyakit VSD Pada Lahan Yang Dirawat}

Persentase serangan penyakit VSD pada lahan yang dirawat dapat dilihat pada Tabel 2 seperti di bawah ini.

Tabel 2. Tanaman Kakao yang Terserang Penyakit VSD pada Lahan yang Dirawat

\begin{tabular}{clcc}
\hline $\begin{array}{c}\text { No. } \\
\text { pohon }\end{array}$ & Bagian tanaman terserang VSD & $\begin{array}{c}\text { Tanaman } \\
\text { sakit VSD }\end{array}$ & $\begin{array}{c}\text { Tanaman } \\
\text { tidak sakit VSD }\end{array}$ \\
\hline 1 & Tidak Ada & $\checkmark$ & $\checkmark$ \\
2 & Ranting ada noktah coklat & & $\checkmark$ \\
3 & Tidak Ada & & $\checkmark$ \\
4 & Tidak Ada & & $\checkmark$ \\
5 & Tidak Ada & & $\checkmark$ \\
6 & Tidak Ada & & $\checkmark$ \\
7 & Tidak Ada & & $\checkmark$ \\
8 & Tidak Ada & $\checkmark$ & \\
9 & Tidak Ada & $\checkmark$ & \\
10 & Pucuk Daun Layu, mati & & \\
11 & Pucuk Daun Layu, mati & $\checkmark$ & $\checkmark$ \\
12 & Tidak Ada & $\checkmark$ & $\checkmark$ \\
13 & Pucuk Daun Layu, mati & & $\checkmark$ \\
14 & Pucuk Daun Layu, mati & & $\checkmark$ \\
15 & Tidak Ada & & $\checkmark$ \\
16 & Tidak Ada & & \\
17 & Tidak Ada & & \\
18 & Tidak Ada & & \\
19 & Tidak Ada & & \\
20 & Ranting ada noktah coklat & & \\
\hline
\end{tabular}

Dari Tabel 2 di atas dapat dihitung persentase tanaman kakao yang terserang penyakit VSD pada lahan yang dirawat yaitu :

$$
\begin{aligned}
& P=n / N \times 100 \% \\
& P=6 / 20 \times 100 \%=30 \%
\end{aligned}
$$

Pada lahan tanaman kakao yang dilakukan perawatan intensif seperti mengatur jarak tanam kakao, melakukan pengendalian terhadap hama dan penyakit, menjaga kebersihan lahan dengan melakukan penyiangan maka serangan penyakit Vascular Streak Dieback hanya sekitar $30 \%$. Hal ini menandakan serangan penyakit ringan karena lahan tanaman tersebut dirawat dan dikelola dengan baik.

Diterbitkan oleh Program Studi Agroteknologi Fakultas Pertanian Universitas Batanghari Jambi Halaman 105 
Jurnal Media Pertanian Vol. 3 No. 2 Tahun 2018 Hal. 99 - 106

Media Komunikasi Hasil Penelitian dan Review Literatur Bidang Ilmu Agronomi ISSN print $2503-1279$

ISSN online $2581-1606$

\section{Pengamatan Mikroskopis \\ Pengamatan secara mikroskopis terhadap jamur pathogen penyebab penyakit dapat \\ Dilihat pada Gambar 3 di bawah ini.}

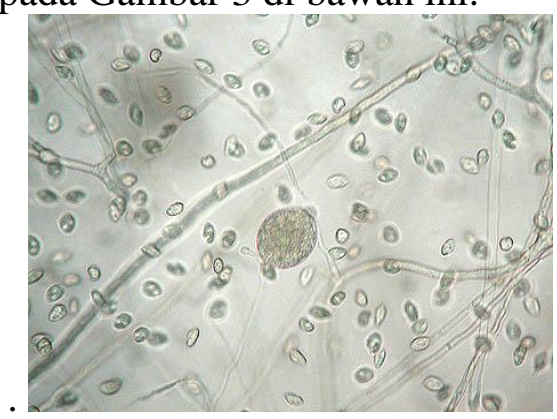

Gambar 3. Oncobasidium theobromae

Vascular Streak Dieback (VSD) disebabkan oleh jamur Oncobasidium theobromae. Jamur membentuk struktur sporangium yang berbentuk seperti buah peer. Sporangium dapat berkecambah secara langsung atau membentuk spora kembara yang dapat berenang. Jamur dapat membentuk struktur tahan klamidospora dan spora seksual oospora (Semangun, 1990).

\section{KESIMPULAN}

Dari hasil penelitian yang telah dilakukan dapat disimpulkan bahwa persentase serangan penyakit Vascular Streak Dieback (VSD) yang disebabkan oleh jamur Oncobasidium theobromae. pada lahan yang tidak dirawat adalah 80 $\%$, yang berarti serangan penyakit ini termasuk berat karena lebih setengahnya tanaman kakao terserang penyakit. Sedangkan pada lahan yang dilakukan perawatan intensif serangan penyakit busuk buah hanya $20 \%$ ini berarti serangan penyakit ringan.

\section{DAFTAR PUSTAKA}

Abadi, A. 2005. Ilmu Penyakit Tumbuhan. Bayu Media. Jakarta

Agrios, G. 1999. Ilmu Penyakit Tumbuhan. Gajah Mada University Press. Jogyakarta.

Biro Pusat Statistik Jambi, 2014. Jambi Dalam Angka.

Diretorat Jendral Perkebunan, 2015. Statistik Perkebunan Indonesia Komoditas Kakao 2014 - 2016. Jakarta

Semangun, H. 1990. Penyakit-Penyakit Tanaman Perkebunan di Indonesia. Gajah Mada University Press. Jogyakarta.

Sinaga, M. 2004. Dasar-dasar Ilmu Penyakit Tumbuhan. Penebar Swadaya. Jakarta.

Sudiyanto, 2009. Pedoman Bercocok Tanam Cokelat. Direktorat Jenderal Perkebunan. Jakarta.

Susanto, F.X., 2010 . Tanaman Kakao Budidaya Pengolahan Hasil. Kanisius,.Jokjakarta.

Syamsulbahri, 2008. Bercocok Tanam Tanaman Perkebunan Tahunan, Gajah Mada University Press. Yokyakarta.

Diterbitkan oleh Program Studi Agroteknologi Fakultas Pertanian Universitas Batanghari Jambi Halaman 106 